\title{
木材チップを骨材とした団粒舗装による自然な斜面の造成
}

\begin{abstract}
大澤和幸・岡田 拓
摘要：間伐や伐採などにより発生する廃木材を有効に利用することが求められており，特にのり面などの緑 化に使用する場合，自然を復元するという目的と，廃木材の有効利用という目的を両立するものとして注目さ れている。しかし，現在一般的に行われている緑化手法は，均一に整形されたのり面に対して，均一に植生基 盤を造成するものであり，本来自然環境には久かせない“多様性”が失われる事が多い。そこで，廃木材のチ ップを使用し,アスファルト乳剂をバインダーとして使用することで, 侵食に強い生育基盤を作ること, また, 凹凸のあるのり面に適用可能なものとすることで，より自然な多樣性のある斜面を造成することを目的として 緑化工法を開発し，一定の成果が得られたので報告する。

キーワード : 斜面緑化，材チップ，生葾（団粒）秿装，耐水性団粒, 生物多様性，リサイクル资材
\end{abstract}

1. はじめに

$\mathrm{CO}_{2}$ 削減やリサイクルという観点から, 各方面で廃木材 の有効利用が緊急の課題となっている昨今，緑化資材とし て廃木材を利用することが求められている。

一方，斜面緑化においては，斜面を平滑に整形し均一な 厚さに造成した生育基盤で，果たして周辺環境と調和した 自然復元ができるだろうかといった反省や批判の声が高ま っている。永い年月を経て自然の作用で形成された斜面は 凹凸が著しく，様々な環境が生じるため多様な植生が成立 し，多様な生物が共生する場となっている。

そこで, (1)現地で発生する廃木材をチップ化し, 堆肥化 することなく骨材として使用すること，(2)凹凸のある崩壞 地や放置斜面へ，ラス金網張りや枠工などの緑化基整工な しで自立することのできる生育基盤であること，(3)更には 植生に適した生育基盤とすることを目的として生態舗装工 法「バイオファルト工法」を開発した。
生態舗装工「バイオファルト工法」は，木材チップを骨 材とした団粒舗装により雨滴に対する耐侵食性を持ち, 浸 透水の減少により表層崩壊を防ぐ, 斜面の安定と生態回復 を両立させることを目的とした自然復元工法である。

使用する主な材料は，舗装材としてアスファルト乳剂と 木材チップ, 植生材として粘土, 肥料, 植物性緉維等であ る。

本工法の最大の特長は, 大量の木材チップを生のまま骨 材として使用し，アスファルト乳剂と粘土と水を混合し， 吹き付け時に混合する団粒化剂により，スラリーの団粒化 と同時に乳化を破壊して耐水性の強固な団粒構造を作るこ とにある。

更に木材チップをアスファルトによりコーティングする 事で, 分解を遅速化させ窒素飢餓による植生への影響を解 消するばかりでなく, 骨材としての効果を持続させること ができると考える。施工のフローを図1に示す。

\section{2. 生態舗装工法の概要}

高次団粒基材吹付機

$$
\text { ソイルシーダー } 2
$$

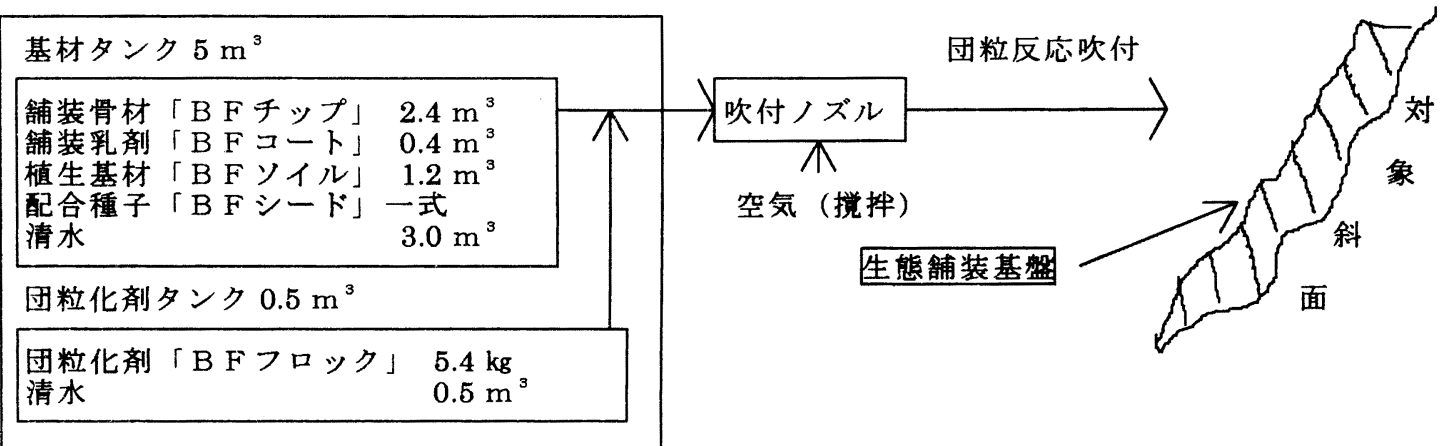

図 1 生態舗装エの施エフロー 


\section{3. 試験方法}

前述の開発の目的を満足する工法であるかどうかを確認す るため，以下の 3 項目について試験を行った。

\section{1 チップ化する樹種による植生への影響}

生の木材チップを使用するので植物に障害とならないか, また, チップ化する樹種の種類による植生への影響があるか どうかを調べることを目的として行った。

樹種は，岐阜県八百津町役場より提供されたアカマツ (Pinus dinsiflora Sieb.et Zucc), ス ギ ( Cryptomeria japonica D. Don), ヒノキ(Chamaecyparis obtusa Endl) を用いた。現地発生廃材としては, 枝葉が多くなると思われ るため, 各々の樹種の枝, 特に葉の部分を多量に混ぜ粉砕機 で粉砕し， 20 mメッシュの節を通過させたチップを使用し た。上記の材料で本工法の生育基盤を作成し, 縦 $50 \mathrm{~cm}$, 横 30 $\mathrm{cm}$ ，梁さ $10 \mathrm{~cm}$ の育苗箱に詰め，45 度の傾斜台に設置した。 供試植物はコマッナギ ( Indigofera pseudo-tinctoria Matsum.) とした。播種量は 1 供試体当たり $3 \mathrm{~g}$ とした。測 定項目は，成立本数と上位 5 本の樹高とした。

3.2 基盤の耐侵食性

造成した生育基盤の耐侵食性を調べるために, 耐降雨試験, 而波浪試験，耐流水性試験を行った。

3.2 .1 耐降雨試験 繸 $90 \mathrm{~cm}$, 横 $90 \mathrm{~cm}$, 樑さ $5 \mathrm{~cm}$ の木枠に 本工法の基盤を詰めをもの, 対照としてローム土を土谼硬度 15 mに填圧したものを供試体とした。これらの供試体を， 傾斜角 45 度に設置し, 穴径 $0.5 \mathrm{~m}$ の散水ノズルから直径約 2 mm雨滴を $5 \mathrm{~m}$ の高さから $100 \mathrm{~mm} / \mathrm{hr}$ で散水し, 流出土量を測 定した。試験は, 施工直後, 1 週間後, 1 力月後に行った。 3.2 .2 耐波浪性試験 縦 $60 \mathrm{~cm}$ 横 $30 \mathrm{~cm}$ の梁さ $3 \mathrm{~cm}$ の育苗バ ットに本工法の基盤を $1 \mathrm{~cm}$ 程度に詰め, 安定後に波高 $5 \mathrm{~cm}$, 波数 43 回/分の波浪試験機に設置し, 3 ヶ月間 継続して波にあてた。

3.2.3 耐流水性試験 幅 $30 \mathrm{~cm}$, 深さ $30 \mathrm{~cm}$ の流路溝に毎分 400 リットルの水が流速 $2 \mathrm{~m}$ 秒で流れるように設置し, 底

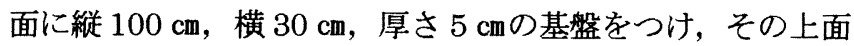
を水が流れるようにした．基盤の表面と流路溝の底面を合わ せ，段差をなくすようにした。1 カ月間継続して試験を行っ た。

3.3 植物の生育状態

静岡県御殿場市の株彩光緑化試験地斜面において, 当工法 基盤を施工し植生の生育を観察した。現地は平均傾斜が 1:1.2 の黒ぼく土の盛土で，表層に直径 $20 \sim 50 \mathrm{~cm}$ 大の喽が点在 している。ラス金網等の緑化基礎工はせず， $5 \mathrm{~m}^{3}$ の基材を $150 \mathrm{~m}^{2}$ に吹き付け施工した。使用種子と播種量は，中マ八ギ

(Lespedeza bicolor var. japonica Nakai) が $1.0 \mathrm{~g} / \mathrm{m}^{2}$, ヤ

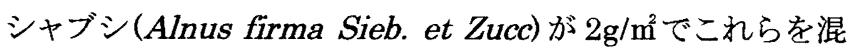
播した。施工日は, 平成 12 年 4 月 20 日である。測定は, 100 $\mathrm{m}^{2}$ の方形枠を設置し，枠内の成立本数と上位 30 本の樹高を 測定した。

\section{4. 結果}

4.1 チップ化する樹種による植生への影響

試験の結果を表 1 に示す。対照がないので比較はできない が，どの樹種も大差なく発芽・生育が認められた。

4.2 基盤の耐侵食性

4.2.1 耐降雨試験 試験の結果を表 2 に示す。施工直後で も流出土量は, 全体の $0.2 \%$ 程度で, 耐侵食性が認められた。 耐侵食性があるのは，施工時にアスファルト乳剤の乳化物を 破壊して団粒反応させることで，基盤が乾燥する前からアス ファルトの接着性がでているためと考える。また, 施工後 1 週間以降の安定した基盤では, ほとんど侵食がみられなかっ た。

4.2.2 耐波浪性試験 表面のチップの剥離がいくつか見ら れたものの，基盤の崩壊，侵食等は見られなかった。

4.2.3 耐流水性試験 表面のチップの剥離がいくつか見ら れたものの，基盤の崩壊，侵食等は見られなかった。

4.3 植物の生育状態

各樹種の発芽数と樹高の測定結果を表 3 と図 2 亿示す。ま た, 実地試験の施工直後と施工後 3 力月半後の写真を写真 1 ～ 2 に示す。従来の緑化工法と同様澄芽, 生育しでいる ことが確認された。また, 施工後, 約 1 年経過後も生育基 盤の大きな崩落や落石は認められず，緑化基礎工無しでの安 定性が認められた。

\section{表 1 チップ化する樹種による植生への影響}

$\left(\right.$ 本 $\left./ \mathrm{m}^{2}, \mathrm{~cm}\right)$

\begin{tabular}{|c|c|c|c|c|c|c|c|}
\hline \multirow[t]{2}{*}{ 経過日数 } & \multicolumn{2}{|c|}{1 力月 } & \multicolumn{2}{|c|}{2 力月 } & 5 力月 & \multicolumn{2}{|c|}{10 力月 } \\
\hline & $\begin{array}{l}\text { 成立 } \\
\text { 本数 }\end{array}$ & 樹高 & $\begin{array}{l}\text { 成立 } \\
\text { 本数 }\end{array}$ & 樹高 & $\begin{array}{l}\text { 成立 樹高 } \\
\text { 本数 }\end{array}$ & $\begin{array}{l}\text { 成立 } \\
\text { 本数 }\end{array}$ & 樹高 \\
\hline 使用チップ & & & & & & & \\
\hline マツ & 346 & 2.7 & 306 & 8.2 & 28630.0 & 223 & 36.0 \\
\hline スギ & 313 & 3.2 & 306 & 14.6 & 29328.5 & 234 & 34.2 \\
\hline ヒノキ & 333 & 2.5 & 195 & 8.4 & 18622.8 & 180 & 27.4 \\
\hline
\end{tabular}

表 2 人工降雨による流出土量

\begin{tabular}{lcccc} 
& & & & $\left(\mathrm{g} / \mathrm{m}^{2}\right)$ \\
\hline 降雨時間 (分) & $0 \sim 10$ & $10 \sim 20$ & $20 \sim 30$ & 計 \\
\hline 設置後日数 & & & & \\
施工直後 & 11.5 & 14.2 & 13.6 & 39.3 \\
1 週間後 & 0.1 & 2.1 & 2.2 & 4.3 \\
1 ヶ月後 & 0.0 & 0.2 & 0.3 & 0.5 \\
対照 (口-4土) & 850 & 1240 & 1420 & 3510 \\
\hline
\end{tabular}

\section{表 3 導入植物の成立本数の推移}

\begin{tabular}{lrrrrc} 
& & & & $\left(\right.$ 本 $\left./ 100 \mathrm{~m}^{2}\right)$ \\
\hline 経過日数 & 1 カ月 & 2 カ月 & 3 カ月 & 4 カ月 & 5 力月 \\
\hline 樹種 & & & & & \\
ヤマハギ & 521 & 1530 & 1411 & 1290 & 1085 \\
ヤシャブシ & 285 & 520 & 192 & 185 & 144 \\
\hline
\end{tabular}




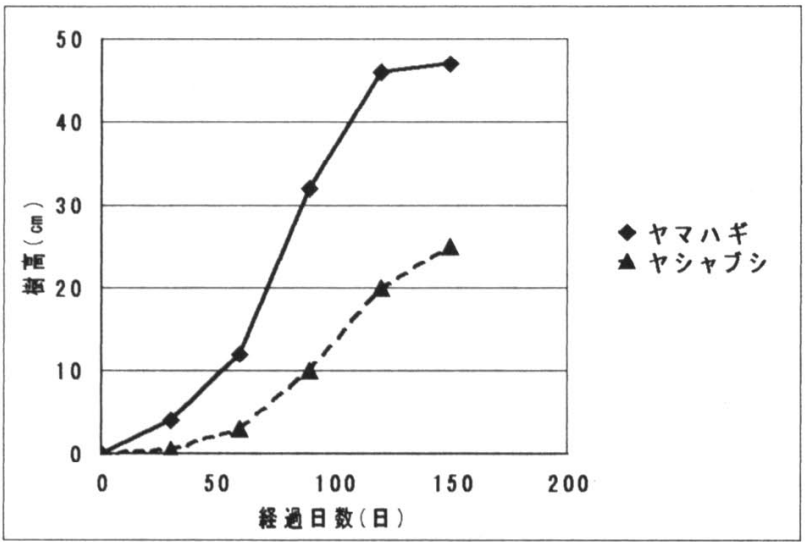

図 2 導入樹種の平均樹高の推移

\section{5. 考察}

以上の試験から考察寸ると, 生チップの使用に関しては, 今回の代表的な樹種による試験では, 発芽, 生育の障害がほ とんど認められないことから，木材チップを堆肥化すること なく有効に利用できると考えられる。

植生に関しては, バインダーとしてアスファルト乳剂を使 用し基盤が固くなることから, 導入植物の発芽, 生育に関し て問題を生じないかという懸念があった。しかし, 今回の試 験条件においては導入植物が発芽, 生育していることが認め られた。実際の現場においては, 気温, 降雨量, 地山の性質 等様々な条件があるため一概にはいえないが, 植物の導入が 可能な基盤であるといえると考える。これは，木材チップを 骨材とし，アスファルトと粘土を団粒化することにより，適 度な空隙のある生育基盤を得られたためと考えられる。

また，本生育基盤自体が高い耐侵食性をもつこと，また侵 食を防止することにより，地山の表層を安定化させる効果が あると考えられるため, 本生育基盤がラス金網などの緑化基 礎工が無くても自立でき, 生育基盤を保護する目的としての ラス金網等は不要と考えられる。しかし，当然ながら本工法 で斜面の大きな崩壊を抑えることまでは期待するものではな い。

なお，本生育基盤は波浪や流水に対し優れた耐性をもつこ とが示された。よって, 本工法は道路のり面だけでなく, ダ 么湖湛水面等の水辺の緑化にも応用が期待できる。

\section{6. おわりに}

今回行った試験により，本工法は開発の目的を満たすもの

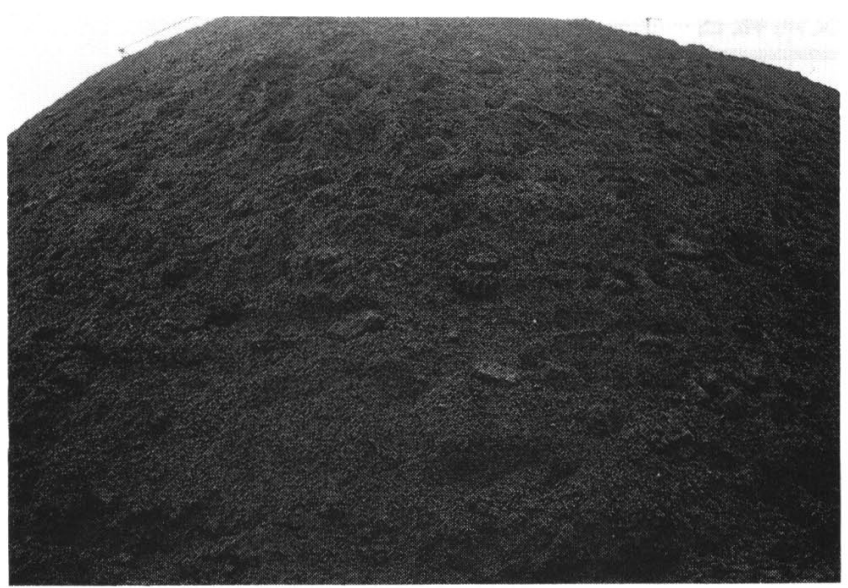

写真 1 実地試験施工直後

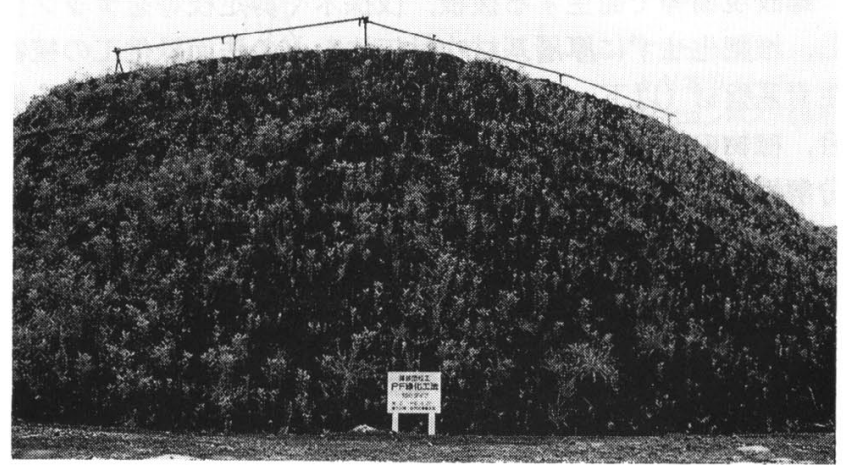

写真 2 実地試験施工後 3 力月半

と認められ，実用段階に入っている。しかしながら， 様々な条件下での施工事例により，本工法に改良の余 地があることも示された。今後は, それらの事例の追 跡調査を行い，本工法の改良に努めたい。

一方，本工法の施工管理については，凹凸のある自然な斜 面を復元することを目的とすることから, 均一な厚さを求め るのではなく，単位面積当たりの吹き付け量で管理する。ま た, 植物の成立については, 木本植物の場合, 発芽適期を過 ぎた時期で導入種が $100 \mathrm{~m}^{2}$ 当たり 30 本以上成立しているこ ととする。以上 2 点を, より自然な斜面を作るための，新 しい管理基準として提案する。

(2001.7.1 受理) 